Вісник економіки транспорту i промисловості : зб. наук. праць, - Харків : УкрДАЗТ. - 2005. - № 9-10. - С. 140-145

13 Соломніков, І.В. Інвестиційне забезпечення техніко-технологічного оновлення підприємств залізничного транспорту / I.B. Соломніков // Вісник економіки транспорту і промисловості. - № 60, 2017. - С. 223 -228.

14. Еврокомиссия одобрила программу поддержки перераспределения грузов в пользу железнодорожного и водного транспорта https://railwaypublish.com/news/7858-evrokomissiiaodobrila-programmy-podderjkipereraspredeleniia-gryzov-v-polzyjeleznodorojnogo-i-vodnogo-transporta.html

15. Соломніков, I.B. Державна підтримка техніко-технологічного оновлення підприємств залізничного транспорту [Електронне наукове видання]/ I.B. Соломніков // Мукачівський державний університет. - Випуск № 6/2016. - C. 215-219. - режим доступу: http://economyandsociety.in.ua/journal/6_ukr 136.pdf

16. Непран, А.В. Роль запозичень у фінансуванні інвестиційної діяльності підприємств реального сектору економіки / А.В. Непран, I.C. Тимченко, Н.М.
Каменева // Вісник економіки транспорту і промисловості. - № 60, 2017. - С. 216-223.

17. Railway Reform in Germany: Restructuring, Service Contracts, and Infrastructure Charges [Text] / Von der Fakultät VII - Wirtschaft und Management der Technischen Universität Berlinzur Erlangung des akademischen Grades, Berlin, 2008 - 236 p.

18. Матвеева Н.А. Инновационные модели инвестиционной стратегии управления предприятиями железнодорожного транспорта // Бюллетень транспортной информации, №9 (171), сентябрь 2009, С. 14 -17.

19. Лапін П. В. Виробничі загрози економічної безпеці підприємств залізничного транспорту [Текст] / П. В. Лапін // Вісник економіки транспорту i промисловості. - № 55, 2016. - С. 41 - 50

20. Цвєтков B. В. Державне управління: основні фактори ефективності (політико-правовий аспект)/ В.В. Цвєтков. - Х. : Право, 1996. -192 с.

21. Ефективність державного управління в умовах реформ: наук. розробка / Ю. В. Ковбасюк, Н. Г. Джинчарадзе, Ю. П. Сурмін [та ін.]. - К. : НАДУ, 2014. - 76 с.

DOI 10.18664/338.47:338.45.v0i64.149573

УДК 656.078

\title{
ТЕОРЕТИЧНІ ЗАСАДИ МОДЕРНІЗАЦІЇ ПІДПРИСМСТВ ЗАЛІЗНИЧНОГО ТРАНСПОРТУ УКРАЇНИ
}

\author{
Корінь М.В., к.е.н., доцент, \\ Сендюк В.Е., магістр, \\ Муквіч О.С., магістр (УкрДУЗТ)
}

В статті вивчено теоретичні основи модернізації, щуо дозволило представити авторське розуміння даного терміну. Запропоновано під модернізацією підприємств залізничного транспорту розуміти прочес якісних перетворень на підприємствах галузі за рахунок освоєння сучасних технологій організації транспортного прочесу та оновлення інфраструктури, спрямованих на підвищення енего- і ресурсоефективності, 
рівня безпеки в галузі, покращення ї̈ фінансово-економічного становища та в цілому конкурентоспроможності на ринку перевезень. Проаналізовано сьогочасну ситуачію зі станом основних фондів залізничного транспорту, щзо дозволило обтрунтувати необхідність реалізаиії саме модернізащійних перетворень в галузі. Визначено основні напрямки модернізаиії таких ключових для залізничного транспорту бізнес-вертикалей, як вантажні перевезення та логістика, пасажирські перевезення, інфраструктура, послуги тяги, виробництво та сервіс.

Ключові слова: залізничний транспорт, модернізація, напрямки, бізнесвертикалі, знос.

\title{
ТЕОРЕТИЧЕСКИЕ ОСНОВЫ МОДЕРНИЗАЦИИ ПРЕДПРИЯТИЙ ЖЕЛЕЗНОДОРОЖНОГО ТРАНСПОРТА
}

\author{
Коринь М.В., к.э.н, доцент, \\ Сендюк В.Э., магистр, \\ Муквич О.С., магистр (УкрГУЖТ)
}

В статье изучено теоретические основы модернизации, что позволило представить авторское понимание данного термина. Предложено под модернизацией предприятий железнодорожного транспорта понимать процесс качественных преобразований на предприятиях отрасли за счет освоения современных технологий организации транспортного прочесса и обновления инфраструктуры, направленных на повышение энего- и ресурсоэффективности, уровня безопасности в отрасли, улучшение ее финансово-экономического положения и в целом конкурентоспособности на рынке перевозок. Проведен анализ существующей ситуации относительно состояния основных фондов железнодорожного транспорта, что позволило обосновать необходимость реализации именно модернизационных преобразований в отрасли. Определень основные направления модернизации таких ключевых для железнодорожного транспорта бизнес-вертикалей, как грузовые перевозки и логистика, пассажирские перевозки, инфраструктура, услуги тяги, производство и сервис.

Ключевые слова: жселезнодорожнный транспорт, модернизация, направления, бизнес-вертикали, износ.

\section{THEORETICAL BASES OF MODERNIZATION OF RAILWAY TRANSPORT ENTERPRISES}

\author{
Korin M., candidate of economic sciences, associate professor, \\ Senduk $V$. , master, \\ Mukvych O., master (USURT)
}

The article states that for today the modernization of key business management vertical lines is the tool that will enable PJSC «Ukrzaliznytsja» to become a leader in the European market of transport and logistics services by bringing the quality of transport and logistics services to the requirements and standards of the EU. The study of the stages of the evolution of the theory of modernization and approaches to the interpretation of the content of this economic category, allowed to present the author's understanding of this term. It is proposed to modernize railway enterprises to understand the process of qualitative transformations at the enterprises of the industry through the development of modern technologies for the

Вісник економіки транспорту і промисловості № 64, 2018 
organization of the transport process and the updating of the infrastructure aimed at increasing the profit and resource efficiency, the level of security in the industry, improving its financial and economic situation and overall competitiveness in the market transportation The present situation with the state of fixed assets of railway transport was studied, which allowed to establish a significant level of their workability. It is determined that the critical level of depreciation of fixed assets is one of the reasons for the deterioration of the performance indicators of PJSC «Ukrzaliznytsja», increase of resource and energy consumption of the transport process, decrease of demand for transportation, and, consequently, decrease of competitiveness of Ukrainian railways in the European market of transport services. On this basis, the necessity of realization of modernization transformations in the industry is substantiated. Taking into account that at present in PJSC «Ukrzaliznytsja» there is a change in the corporate governance system due to the creation of new business verticals, the formation of which will take place by transferring to the balance of currently available fixed assets in the industry, the main directions of modernization of such key business lines for rail transport, such as freight transport and logistics, passenger transportation, infrastructure, traction services, production and service.

Keywords: railway transport, modernization, directions, business vertical, demolition.

\section{Постановка}

проблеми.

Реформаційні процеси, що наразі мають місце на залізничному транспорті України, спрямовані на активне включення українських залізниць в систему транс'європейських транспортних зв'язків та забезпечення реалізації вигідного для країни транзитного потенціалу. Однак, попри численні заходи щодо входження ПАТ «Укрзалізниця» в європейський транспортний простір наразі в галузі наявні численні асиметрії розвитку, що обмежують можливість іiі повноцінної інтеграції в Європу. В значній мірі наявні асиметрії зумовлені технологічною відсталістю залізничного транспорту від рівня розвитку європейських залізниць, що відбивається в нагромадженні фізично i морально зношеного рухомого складу, залізничної інфраструктури, контактної мережі, засобів зв'язку тощо.

$$
\text { Особливу загрозу фактор }
$$

технологічної відсталості становить для безпеки та привабливості перевезень, а відповідно й операційної ефективності галузі в умовах піi переходу до моделі управління активами за бізнесвертикалями. Адже згідно зі Стратегією розвитку ПАТ «Українська залізниця» кожна бізнес-вертикаль буде створення на основі фондів, що наразі експлуатуються у відповідних підрозділах, функціонуватиме як окремий суб'єкт 3 обслуговування певного сегменту ринку. Створення бізнес-вертикалей шляхом передачі критично зношених фондів у їх структуру наперед означає збереження низького рівня ефективності компанії, а тому виникає необхідність в пошуку напрямків реалізації модернізаційних перетворень на підприємствах залізничного транспорту.

Аналіз останніх досліджень $i$ публікацій. У сучасній економічній науці існує багато досліджень, присвячених проблематиці модернізації. До числа найбільш відомих науковців, які обіймаються питанням теоретичного осмислення процесу модернізації, належать Бужимська К., Мамалуй О., Михальченко М., Пашута М., Петрович Й., Шкільнюк О. та інші [1-5].

Пошуку інструментів модернізації підприємств залізничного транспорту присвячені публікації таких провідних вчених транспортної галузі, як Дикань В., Зубенко В., Калініченко Л., Корінь М., Маслова В., Токмакова I., Шраменко О. та інші [6-10]. Незважаючи на достатню увагу вчених до проблеми подолання критичного стану основних фондів галузі, нові умови функціонування залізничного транспорту, що проявляються в створенні бізнесвертикалей для обслуговування окремих

Вісник економіки транспорту і промисловості № 64, 2018 
сегментів ринку залізничних перевезень, актуалізують питання пошуку напрямків модернізації ключових для галузі бізнесвертикалей. Саме тому, метою статті $\epsilon$ теоретичне осмислення змісту категорії «модернізація підприємств залізничного транспорту» та обгрунтування напрямків їі реалізації в ключових для залізничного транспорту бізнес-вертикалях.

Виклад основного матеріалу дослідження. Термін «модернізація» походить від французького «modernisation», що означає оновлення, удосконалення, надання будь-чому сучасного вигляду, переробка відповідно до сучасних вимог [11]. Основні ідеї теорії модернізації були закладені в XVI ст. і розвивають по теперішній, що зумовило виникнення значних дискусій щодо визначення змісту самої категорії «модернізація». В цілому в науковій літературі вченими виділяється 4 етапи розвитку теорії модернізації, кожен 3 яких відображає зміну поглядів на модернізацію під впливом розвитку науково-технічного процесу. Так, перший етап - це етап ранньої індустріальної (мануфактурної) модернізації, що припадає на XVI ст. середина XVIII ст.; другий етап індустріальної модернізації (кін. XVIII ст. - середина XIX ст.); третій етап розвитку теорії модернізації - пізня індустріальна модернізація (I пол. XX ст.) і сучасний етап, розпочався з середини XX століття та триває по теперішній час - період постіндустріальної модернізації. Етапи еволюції теорії модернізації подано в таблиці 1.

Етапи еволюичї теорії модернізаичї [12]

\begin{tabular}{|c|c|}
\hline$\ddot{i}$ & Коротка характеристика \\
\hline $\begin{array}{c}\text { Період народження та } \\
\text { стрімкого росту дослідження } \\
\text { модернізаційних процесів в } \\
\text { класичній версії / друга } \\
\text { половина 1950-х - перша } \\
\text { половина 1960-х рр. / } \\
\end{array}$ & $\begin{array}{c}\text { Модернізація розглядалася як єдиний глобальний процес переходу } \\
\text { суспільств від традиційності до сучасності на основі } \\
\text { розповсюдження існуючих ідей і технологій з європейського центру } \\
\text { по всьому світу. Представники класичної теорії модернізму } \\
\text { вважали, що перехід від традиційності до сучасності зумовлює зміни } \\
\text { у всіх сферах життя } \\
\end{array}$ \\
\hline $\begin{array}{c}\text { Критичний період / кінець } \\
\text { 1960-х - 1970-ті pp./ } \\
\text { Валерстайн I. }\end{array}$ & $\begin{array}{c}\text { Труднощі реалізації теорії модернізації країнами третього світу, } \\
\text { оскільки країни не завжди мали у розпорядженні необхідні ресурси. } \\
\text { Суспільна критика дала поштовх представникам і прихильникам } \\
\text { теорії модернізму усунути некоректні теоретичні складові } \\
\text { модернізаційної течії та вдосконалити їх }\end{array}$ \\
\hline $\begin{array}{c}\text { Посткритичний період / 1980-х } \\
\text { pp. / Соу Е., Хантінгтон С. }\end{array}$ & $\begin{array}{c}\text { Представники школи модернізації відмовились розглядати } \\
\text { модернізацію як рух до західних інституцій і прийшли до висновку, } \\
\text { що країна може розвиватись, вибравши власний, оригінальний, шлях } \\
\text { на основі національних моделей модернізації з врахуванням } \\
\text { національних традицій }\end{array}$ \\
\hline $\begin{array}{l}\text { Період неомодернізаційного та } \\
\text { постмодернізаційного аналізу / } \\
\text { кінець 1980-х - 1990-х pp./ } \\
\text { Тіріакян Е., Штомпка П., Цапф } \\
\text { В. }\end{array}$ & $\begin{array}{c}\text { Становлення неомодернізаційного та постмодернізаційного аналізу } \\
\text { зумовлено грандіозними трансформаціями у країнах Центрально- } \\
\text { Східної Європи та Євразії. Основні теоретичні положення даного } \\
\text { етапу: відмова від розуміння модернізації як руху в сторону } \\
\text { західних цінностей, визнання можливості власних оригінальних ідей } \\
\text { розвитку; визнання позитивної ролі традицій при здійсненні } \\
\text { модернізаційних перетворень; чинник історії; відмова від } \\
\text { трактування модернізації як єдиного процесу системної } \\
\text { трансформації; циклічність природи модернізації }\end{array}$ \\
\hline $\begin{array}{c}\text { Сучасний етап / } \\
\text { Амосов О.Ю. }\end{array}$ & $\begin{array}{c}\text { Стрімка зміна стадій росту на макрорівні (системній кризі передує } \\
\text { соціально-економічна сталість у більшості країн, а подолання кризи } \\
\text { супроводжується загостренням суперечностей у суспільстві, } \\
\text { збільшенням соціальних трансформацій, зміною конфігурації } \\
\text { суспільних матриць), що відповідає постмодернізаційному аналізу в } \\
\text { посткризовий період }\end{array}$ \\
\hline
\end{tabular}


Кожному із зазначених період розвитку теорії модернізація притаманне власне визначення даного поняття. Так, термін модернізації порозглядався як процес переходу до сучасності; як процес впровадження результатів науковотехнічного прогресу та як процес здійснення перетворень. Зокрема, у словнику 3 суспільствознавства [13] поняття модернізації розглядається 3 позиції переходу до нової індустріальної стадії розвитку. В економічному ж словнику при визначенні терміну «модернізація» основна увага акцентується на змісті даного поняття і трактується як впровадження удосконалень, відповідних сучасним вимогам [14].

Серед науковців також не існує єдиного підходу до трактування змісту даної економічної категорії. Так, Пашута М. Т. та Шкільнюк О. М. [4] визначають модернізацію 3 точки зору процесу оновлення та зміни технологічної бази підприємств. Ці науковці розглядають модернізацію в якості ключового чинника зростання техніко-економічних показників діяльності підприємства та посилення його інтенсивного розвитку. Подібним є трактування, запропоноване Петровичем Й., який розглядає модернізацію в аспекті впроваджень досягнень науковотехнічного процесу задля зростання рівня інноваційності

конкурентоспроможності

продукції підприємств всіх галузей економіки [5].

Більш розширеним $\epsilon$ визначення, запропоноване Бужимською К. Цей науковець розглядає модернізацію з точки зору осучаснення, вдосконалення та забезпечення найбільш сучасного рівня розвитку соціально-економічної системи, що досягається за рахунок реалізації економічних, політичних державноправових, психологічних та культурологічних перетворень [1]. Михальченко М. зазначає, що «...модернізація орієнтує суспільство i його структури, сфери на вдосконалювання, просування вперед, на розробку й реалізацію нових цілей, задач, пріоритетів, стратегій. Модернізація - це творчо-перетворююча функція розвитку. Модернізація є незавершеним проектом, i проектом, що ніколи не завершується у глобальному вимірі. Суспільство, яке завершило модернізаційний проект, може вирушати на історичний смітник» [3].

Отже, визначення поглядів на зміст категорії «модернізація» дозволило встановити наступне:

по-перше, модернізація більшістю вчених визначається з точки зору процесу, тобто до іï трактування застосовується в основному процесний підхід;

по-друге, модернізація завжди означає залучення інноваційного фактору інноваційний характер процесу;

по-третє, сфери реалізації модернізації різні - від модернізації технологічної до забезпечення культурних перетворень.

Таким чином, грунтуючись на вище визначеному, під модернізацією підприємств залізничного транспорту доцільно розуміти процес якісних перетворень на підприємствах галузі за рахунок освоєння сучасних технологій організації транспортного процесу та оновлення інфраструктури, спрямованих на підвищення енего- i ресурсоефективності, рівня безпеки в галузі, покращення iii фінансовоекономічного становища та в цілому конкурентоспроможності на ринку перевезень.

Сьогочасна ситуація на залізничному транспорті вказує на нагальну потребу в реалізації саме модернізаційних перетворень в галузі. Адже саме критичний рівень зносу основних фондів $\epsilon$ однією із причин погіршення показників роботи ПАТ «Укрзалізниця», зростання ресурсо- та енергоємності транспортного процесу, падіння попиту на перевезення, а відповідно, конкурентоспроможності українських залізниць на європейському ринку

Вісник економіки транспорту і промисловості № 64, 2018 
транспортних послуг. Згідно 3 статистичними даними вже наразі вичерпали свій експлуатаційний ресурс більше 90 \% фондів галузі [15]. Зокрема, найбільш критичною ситуація є зі станом рухомого складу для виконання як пасажирських, так і вантажних перевезень. Аналіз поточного стану вантажного рухомого складу дозволив встановити, що наразі парк вантажних вагонів зношений на 90 \%, парк вантажних електровозів - на $88 \%$, а парк тепловозів і взагалі на $100 \%$ [16]. Досить складною $є$ ситуація і 3 рухомими складом, призначених для пасажирських перевезень. Зокрема, середній термін експлуатації усього парку пасажирських вагонів наразі становить 27,5 років, а рівень зношеності - $87 \%$. Із загальної кількості електропоїздів робочий парк нараховує лише $37 \%$, а дизель-поїздів i взагалі лише $5 \%$. Масштабної модернізації потребує й залізнична інфраструктура, фізичний знос якої перевищує $60 \%$, у тому числі об'єктів колійного господарства - $86 \%$ [17].

Згідно зі Стратегією розвитку ПАТ «Українська залізниця» до 2021 року наразі відбуваються зміни в системі корпоративного управління галуззю, що пов'язанні 3 формуванням 5 бізнесвертикалей, що націлені на обслуговування окремих сегментів ринку, а саме: бізнесвертикаль вантажні перевезень, бізнесвертикаль пасажирські перевезення, інфраструктура, послуги тяги, виробництво та сервіс [15]. Враховуючи те, що нові бізнес-вертикалі формуються на базі діючих сфер діяльності залізничного транспорту і відповідно, їх створення буде відбуватися шляхом передачі на баланс наразі наявних в галузі основних фондів, то вважаємо за необхідне зупинитися на характеристиці основних напрямків реалізації модернізаційних перетворень у кожній бізнес-вертикалі (рисунок 1).

Перша бізнес-вертикаль «Вантажні перевезення та логістика», діяльність якої пов'язана 3 надання логістичних послуг та послуг в сфері вантажних перевезень.
Враховуючи існуюче становище сфери вантажних перевезень, основними напрямки модернізації даної бізнесвертикалі варто визначити:

- оновлення парку вантажних вагонів шляхом придбання та проведення капітального ремонту існуючих моделей, налагодження спільних виробництв вагонів 3 провідними закордонними компаніями;

- формування i розвиток ефективної збалансованої термінальноскладської мережі на всій території України шляхом створення вантажопереробних терміналів, мультимодальних термінальних комплексів багатоцільового призначення, що надають широкий спектр складських, митних та супроводжуючих послуг;

$$
\text { - розширення портфелю }
$$

транспортних послуг за рахунок переходу до інтегрованих послуг 3 перевезення вантажів «від дверей до дверей» за принципом «одного вікна»;

- впровадження інформаційно-

телекомунікаційних систем обслуговування, в тому числі програм 3 обміну інформацією, баз роботи 3 клієнтами та програм автоматизованого розподілу парку вантажних вагонів між клієнтами тощо;

- запуск нових контейнерних та контрейлерних поїздів, мультимодальних транспортних маршрутів, в тому числі участь у проектах розбудови нових сухопутних маршрутів;

- будівництво

окремих залізничних ліній для обслуговування вантажних перевезень тощо.

До основних напрямків модернізації бізнес-вертикалі «Пасажирські перевезення» варто віднести:

- оновлення парку пасажирських вагонів за рахунок придбання нових типів вагонів та збільшення парку рейкових автобусів, придбання та проведення капітального ремонту моторвагонного рухомого складу; 


\section{ОСНОВНІ НАПРЯМКИ МОДЕРНІЗАЦІЇ БІЗНЕС-ВЕРТИКАЛЕЙ ПАТ «УКРЗАЛІЗНИЦЯ»}

Бізнес-вертикаль «Вантажні перевезення та логістика»

- оновлення парку вантажних вагонів шляхом придбання та проведення капітального ремонту існуючих моделей, налагодження спільних виробництв вагонів з провідними закордонними компаніями;

- формування і розвиток ефективної збалансованої термінально-складської мережі на всій території України шляхом створення вантажопереробних терміналів, мультимодальних термінальних комплексів багатоцільового призначення, що надають широкий спектр складських, митних та супроводжуючих послуг;

- розширення портфелю транспортних послуг за

рахунок переходу до інтегрованих послуг 3

перевезення вантажів «від дверей до дверей» за принципом «одного вікна»;

- впровадження інформаційно-

телекомунікаційних систем обслуговування, в тому числі програм з обміну інформацією, баз роботи з клієнтами та програм автоматизованого розподілу парку вантажних вагонів між клієнтами тощо;

- запуск нових контейнерних та контрейлерних поїздів, мультимодальних транспортних маршрутів, в тому числі участь у проектах розбудови нових сухопутних маршрутів; - будівництво окремих залізничних ліній для обслуговування вантажних перевезень тощо

\section{Бізнес-вертикаль «Інфраструктура»}

Бізнес-вертикаль «Пасажирські перевезення»

- оновлення парку пасажирських вагонів за рахунок придбання нових типів вагонів та збільшення парку рейкових автобусів, придбання та проведення капітального ремонту моторвагонного рухомого складу;

- відновлення інфраструктури вокзальних комплексів, будівництво сучасних

багатофункціональних транспортно-пересадочних центрів як регіонального, так і міжнародного значення;

розширення спектру послуг за рахунок організації руху туристичних поїздів, впровадження мультимодальних пасажирських перевезень, розвитку каналів продажів (збільшення кількості автоматів $з$ продажу квитків, приєднання до пан'європейської системи продажу та глобальних систем бронювання, розвиток кейнтерингу тощо); - оснащення приміського рухомого складу мобільними терміналами обліку і контролю проїзних документів;

- введення системи «соціального замовлення» 3 боку регіональних органів влади шляхом визначення попиту на перевезення з боку пільгових категорій для кожного окремого маршруту та встановлення на цій основі фактичної потреби в субсидіюванні; - будівництво нових залізничних ліній, розрахованих високошвидкісний рух пасажирських поїздів між ключовими пасажирськими хабами;

- впровадження сучасних клірингових технологій, забезпечення максимальної механізації робіт 3 екіпірування поїздів тощо

- забезпечення своєчасного проведення капітальних та поточних ремонтів колії, інженерних споруд, тягових підстанцій та контактної мережі, перехід на систему ремонтного обслуговування залежно від фактичного стану;

- закупівля нового технічного обладнання, технологій та машин для виконання колійних робіт, віддаленої діагностики стану інфраструктури, робіт з обслуговування контактної мережі, пристроїв електропостачання; - проведення подальшої електрифікації ділянок залізниць з розширення їх провізних здатностей, а також ; - впровадження енергоефективних технологій, в першу чергу за рахунок придбання живильних установок, дизель-генераторів, трансформаторів нового типу, радіостанцій, введення в експлуатацію швидкодіючих елегазових вимикачів для тягових підстанціях, пультів управління, системи мікропроцесорного кодового управління, панелей живлення тощо;

- введення автоматизованих систем управління на великих полігонах основних напрямків мережі за рахунок впровадження й спорудження кабельних волоконно-оптичних ліній зв’язку та встановлення цифрового устаткування тощо

\section{Бізнес-вертикаль «Послуги тяги»}

- оновлення парку тягового рухомого складу шляхом придбання нових двосистемних електровозів, односистемних вантажних постійного і змінного струму, а також магістральних вантажних тепловозів і гібридних маневрових тепловозів;

- проведення ремоторизації тягового рухомого складу сучасними силовими установками маневрових та магістральних тепловозів; - оснащення тягового рухомого складу системами автоматизованого контролю рівня використання палива та технічного стану локомотиву;

- впровадження автоматизованої системи планування роботи тягового рухомого складу тощо

\section{«Виробництво та сервіс»}

- уведення сучасних технологій ремонту тягового рухомого складу, в першу чергу високотехнологічного та енергозберігаючого обладнання, технологій ощадливого виробництва, автоматизації виробничих процесів 3 ремонту рухомого складу;

- впровадження системи ремонту тягового рухомого складу залежно від його технічного стану;

- створення спільних з провідними закордонними компаніями виробництв з ремонту та виготовлення запасних частин і в цілому нового рухомого складу; - диверсифікація послуг за рахунок розширення їх спектру в частині створення потужностей для забезпечення сервісного обслуговування рухомого складу як в середині галузі, так і для зовнішніх партнерів, а також надання ремонтних послуг 3 подовження терміну служби рухомого складу тощо 
- відновлення інфраструктури вокзальних комплексів, будівництво сучасних багатофункціональних транспортно-пересадочних центрів як регіонального, так i міжнародного значення;

- розширення спектру послуг за рахунок організації руху туристичних поїздів, впровадження мультимодальних пасажирських перевезень, розвитку каналів продажів (збільшення кількості автоматів 3 продажу квитків, приєднання до пан'європейської системи продажу та глобальних систем бронювання, розвиток кейнтерингу тощо);

- оснащення

приміського

рухомого складу мобільними терміналами обліку і контролю проїзних документів;

- введення системи «соціального замовлення» 3 боку регіональних органів влади шляхом визначення попиту на перевезення з боку пільгових категорій для кожного окремого маршруту та встановлення на цій основі фактичної потреби в субсидіюванні;

- будівництво нових залізничних ліній, розрахованих високошвидкісний рух пасажирських поїздів між ключовими пасажирськими хабами;

- впровадження

сучасних клірингових технологій, забезпечення максимальної механізації робіт 3 екіпірування поїздів тощо.

Модернізація бізнес-вертикалі «Інфраструктура» має проводитися за такими напрямками:

забезпечення своєчасного

проведення капітальних та поточних ремонтів колії, інженерних споруд, тягових підстанцій та контактної мережі, перехід на систему ремонтного обслуговування залежно від фактичного стану;

- закупівля нового технічного обладнання, технологій та машин для виконання колійних робіт, віддаленої діагностики стану інфраструктури, робіт 3 обслуговування контактної мережі, пристроїв електропостачання тощо;

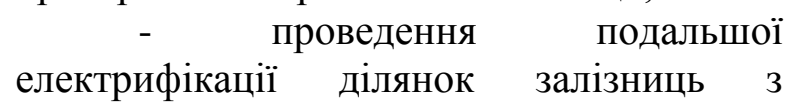

розширення їх провізних здатностей, a також ;

- впровадження енергоефективних технологій, в першу чергу за рахунок придбання живильних установок, дизельгенераторів, трансформаторів нового типу, радіостанцій, введення в експлуатацію швидкодіючих елегазових вимикачів для тягових підстанціях, пультів управління, системи мікропроцесорного кодового управління, панелей живлення тощо;

- введення автоматизованих систем управління на великих полігонах основних напрямків мережі за рахунок впровадження й спорудження кабельних волоконно-оптичних ліній зв'язку та встановлення цифрового устаткування тощо.

Основними

напрямками

модернізації бізнес-вертикалі «Послуги тяги» необхідно визначити:

- оновлення парку тягового рухомого складу шляхом придбання нових двосистемних електровозів, односистемних вантажних постійного i змінного струму, а також магістральних вантажних тепловозів і гібридних маневрових тепловозів;

- проведення ремоторизації

тягового рухомого складу сучасними силовими установками маневрових та магістральних тепловозів;

- оснащення тягового рухомого складу системами автоматизованого контролю рівня використання палива та технічного стану локомотиву;

- впровадження автоматизованої системи планування роботи тягового рухомого складу тощо.

Бізнес-вертикаль «Виробництво та сервіс» може бути модернізовано шляхом:

- уведення сучасних технологій ремонту тягового рухомого складу, в першу чергу високотехнологічного та енергозберігаючого обладнання, технологій ощадливого виробництва, автоматизації виробничих процесів 3 ремонту рухомого складу;

Вісник економіки транспорту і промисловості № 64, 2018 
- впровадження системи ремонту тягового рухомого складу залежно від його технічного стану;

- створення спільних з провідними закордонними компаніями виробництв 3 ремонту та виготовлення запасних частин i в цілому нового рухомого складу;

- диверсифікація послуг за рахунок розширення їх спектру в частині створення потужностей для забезпечення сервісного обслуговування рухомого складу як в середині галузі, так і для зовнішніх партнерів, а також надання ремонтних послуг 3 подовження терміну служби рухомого складу тощо.

Узагальнюючи, варто зазначити, що в умовах реалізації якісно нової для галузі моделі корпоративного управління, яка передбачає передачу активів ПАТ «Укрзалізниця» у підпорядкування новостворених бізнес-вертикалей 3 обслуговування окремих сегментів ринку залізничних перевезень, виконання визначених напрямків модернізації дозволить:

по-перше, підвищити рівень безпеки перевезень та технічну готовність залізничного транспорту до задоволення потреб економіки в безперебійності процесу транспортно-логістичного обслуговування;

по-друге, покращити якість обслуговування за рахунок формування зручних маршрутів, зростання швидкості та комфортності перевезень, впровадження послуг з інтегрованого обслуговування;

по-третє, підвищити операційну ефективність ПАТ «Укрзалізниця» за рахунок оптимізації витрат та зростання продуктивності використання рухомого складу;

вчетверте, активізувати виробничі можливості власних підприємств з ремонту i виробництва рухомого складу та підвищити рівень їх інвестиційної привабливості, інноваційності та економічної ефективності; по-п'яте,

підвищити конкурентоспроможність українських залізниць на європейському ринку транспортно-логістичних послуг та якісно змінити ділову репутацію ПАТ «Укрзалізниця».

Висновок. Таким чином, на сьогоднішній день саме модернізація ключових для галузі бізнес-вертикалей управління $є$ тим інструментом, що дозволить ПАТ «Укрзалізниця» стати лідером на європейському ринку транспортно-логістичних послуг за рахунок доведення рівня якості транспортнологістичного обслуговування до вимог та стандартів СС. Вивчення теоретичних основ модернізації дозволило представити авторське розуміння даного терміну. Запропоновано під модернізацією підприємств залізничного транспорту розуміти процес якісних перетворень на підприємствах галузі за рахунок освоєння сучасних технологій організації транспортного процесу та оновлення інфраструктури, спрямованих на підвищення енего- і ресурсоефективності, рівня безпеки в галузі, покращення іï фінансово-економічного становища та в цілому конкурентоспроможності на ринку перевезень. Вивчено сьогочасну ситуацію зі станом основних фондів залізничного транспорту, що дозволило обгрунтувати необхідність реалізації саме модернізаційних перетворень в галузі. Враховуючи те, що наразі в ПАТ «Укрзалізниця» відбувається зміна системи корпоративного управління за рахунок створення нових бізнесвертикалей, формування яких відбуватиметься шляхом передачі на баланс наразі наявних в галузі основних фондів, визначено основні напрямки модернізації таких ключових для залізничного транспорту бізнесвертикалей, як вантажні перевезення та логістика, пасажирські перевезення, інфраструктура, послуги тяги, виробництво та сервіс.

\section{СПИСОК ВИКОРИСТАНИХ ДЖЕРЕЛ}

1 Бужимська К. О. Теорія модернізації: виникнення, розвиток, 
сучасний стан / К.О. Бужимська // Вісник ЖДТУ. - 2008. - № 2(44). - С. 216-227.

2 Мамалуй О.О. Про зміст механізму модернізації української економіки / О.О. Мамалуй // Вісник Національної юридичної академії України імені Ярослава Мудрого. - 2010. - № 3. - С. 27-35.

3 Михальченко М. Політична реальність в Україні: трансформація, модернізація, революція? [Електронний pecypc] / М. Михальченко. - Режим доступу:

http://dspace.nbuv.gov.ua/bitstream/handle/1 23456789/59635/6-

Mikhalchenko.pdf?sequence=1. - Назва 3 екрана.

4 Пашута М. Т. Інновації: понятійно-теормінологічний апарат, економічна сутність та шляхи стимулювання: навч. посіб. / М. Т. Пашута, О. М. Шкільнюк. - К.: Центр навчальної літератури, 2005. - 118 с.

5 Петрович Й. М. Модернізація промислових підприємств як передумова їх ефективного розвитку [Електронний ресурс] / Й. М. Петрович. - Режим доступу: http://ena.lp.edu.ua:138_Petrovich.pdf.

Назва з екрана.

6 Дикань В.Л. Соціальноекономічна модернізація залізничного транспорту України / В.Л. Дикань, Л.Л. Калініченко // Розвиток методів управління та господарювання на транспорті. - 2012. № 38. - C. 121-131.

7 Зубенко В.О. Визначення пріоритетності інвестування рухомого складу / В.О. Зубенко // Вісник економіки транспорту і промисловості. - 2010. - № 29. - C. 403-405.

8 Корінь М.В. Теоретичні засади підвищення рівня технологічної безпеки залізничного транспорту / М.В. Корінь, В.М. Кривда // Вісник економіки транспорту і промисловості. - 2017. - № 59. - C. 68-75.

9 Маслова В.А. Приоритетные направления инвестиций на усовершенствование техникотехнологической базы в условиях ограниченных финансовых ресурсов / В.А. Маслова, Е.В. Шраменко // Вісник економіки транспорту і промисловості. 2015. - № 52. - C. 132-136.

10 Токмакова I.В. Сучасні підходи до вирішення проблеми оновлення рухомого складу залізничного транспорту / I.B. Токмакова // Вісник економіки транспорту і промисловості. - 2009. - № 25. - C. 82-84.

11 Словник іншомовних слів / За ред. члена-кореспондента АН УРСР О. С. Мельничука. - Київ: Головна редакція української радянської енциклопедії, 1977. $-776 \mathrm{c}$.

12 Гедз М. Й. Еволюція розвитку теорії модернізації / М. Й. Гедз // Економічний простір. - 2014. - № 88. - С. 28-38.

13 Словарь по обществознанию / Ю. Ю. Петрунин, М. И. Панов, Л. Б. Логунова и др.; под ред. Ю. Ю. Петрунина. - 3-е изд. - М.: КДУ, 2006. - 512 с.

14 Азрилиян А. Н. Большой экономический словарь / А. Н. Азрилиян, О. М. Азриелян, Е. В. Калашникова, О. К. Квардакова. - М.: Институт новой экономики, 2007. - 1152 с.

15 Основні аспекти стратегії розвитку ПАТ «Укрзалізниця» 2017-2021 роки [Електронний ресурс]. - Режим доступу:

http://www.uz.gov.ua/about/general_informat ion/. - Назва з екрана.

16 Обговорення довгострокової стратегії зміни тарифів на вантажні перевезення ПАТ «Укрзалізниця» [Електронний ресурс]. - Режим доступу: http://www.uz.gov.ua/press_center/up_to_dat e_topic/451909/. - Назва 3 екрана.

17 Офіційний сайт Міністерства інфраструктури України [Електронний pecypc]. - Режим доступу: http://mtu.gov.ua/ . - Назва з екрана. 